\title{
Characteristics of Sago Noodles as Affected by Varied Concentration of Carbonized Rice Straw-Based Liquid Colorant
}

\author{
Erni Sofia Murtini ${ }^{1, *}$, Cornelia Sertha Lorenzsa ${ }^{1}$ \\ ${ }^{1}$ Food Science and Technology, Brawijaya University, Malang, Indonesia \\ *Corresponding author.Email:erni.murtini@ub.ac.id
}

\begin{abstract}
Utilization of carbonized rice straw (CRS) as a natural black colorant has been widely applied for traditional Indonesian food. This study was aimed to determine the characteristics of sago noodles as affected by different concentrations of liquid CRS added. Randomized Block Design (RBD) with concentration of liquid CRS $(0 \% ; 0.5 \% ; 1 \% ; 1.5 \%) \mathrm{w} / \mathrm{w}$ and 5 replications were used. The data were analyzed by ANOVA (Analysis of Variance) and LSD test (Least Significance Different). The results showed that addition of liquid CRS in varied concentrations significantly affected $(\alpha=0.05)$ on elongation, cooking loss, cooking time and color (Lab) of sago noodles. The higher concentration of CRS added, produced the higher value of elongation, lower cooking loss and cooking time, and darker the color of sago noodles. Sago noodles from the best treatment (addition of 1.5\% dye) based on the Multiple Attribute test had 54.45\% elongation value; $2.72 \%$ cooking loss; 153 seconds cooking time; 29.7 brightness ( $\mathrm{L} *$ ); -2.1 redness (a *) and 3.2 yellowish (b*). It had $13.2 \%$ moisture content; $0.31 \%$ ash content; $0.22 \%$ protein content; $0.04 \%$ fat content; and $85.76 \%$ carbohydrate (by difference). The sago noodles with a $70 \mathrm{~g}$ serving size had $240 \mathrm{Kcal}$ energy.
\end{abstract}

Keywords: sago noodles, physical properties, liquid carbonized rice straw colorant

\section{INTRODUCTION}

Rice straw is the vegetative part of the rice plant, which actually the panicle stems and stems that have been removed from its grain [1]. The carbonized top part of rice straw, namely merang, has been utilized as a natural black colorant for Indonesia traditional food. The black colour from CRS is caused by carbon (C). The carbon could bring black colour on by the combustion process [2]. CRS from merang part of black glutinous type contains carbon $(44,7 \%)$ and minerals [3].

The purified carbon-based commercial black colorant for food has been available with the category of vegetable carbon regulated by code E153 [4] whereas in Indonesia, a vegetable carbon has CI. No. 77266 as the code [5]. There were no data available on the genotoxicity, chronic toxicity, carcinogenicity, and reproductive and developmental toxicity of vegetable carbon [4].

In Indonesia, the application of CRS as colouring agent has been applied to traditional food products such as jongkong cakes, lompong cakes, talam cakes, lapis cakes and black dawet. Further, CRS has been developed in the form of liquid dyes, and it has been applied in wheat noodlemaking [6]. These uses are potentially growing up as the black-colored food trends that also changing in the past two years for example pizza, waffle, ice cream, noodles, pancake and bread.
The common traditional method to prepare black colour is by soaking CRS in the water overnight and filter it to remove undissolved materials. However, this method has weakness such as produced secondary waste and it is less efficient. Therefore, further research on the application of CRS in form of a liquid colorant is done. This method utilizes the whole part of CRS and it is more practical for food products making, one of them is applied in sago noodles making.

Sago noodles are non-gluten noodles containing resistant starch; therefore, it contributes to increasing the functional food product choices. Gluten-free food products have received a serious response by world food experts along with the increasing number of sufferers of Celiac Disease (CD) and people with gluten-intolerance. The average increasement of $\mathrm{CD}$ incidents is estimated at 9,77 $\pm 8,27 \%$ per year in worldwide [7]. Meanwhile, Indonesia is the 7th country with the highest prevalence of diabetes [8]. This study was aimed to determine the concentration addition's effect of liquid carbonized rice straw on the physical characteristics of sago noodles as a form of diversification colour product to attract consumers as well as optimize the potential utilization of local raw materials.

\section{METHODS}

The material used in this study was merang part of black glutinous rice straw which was treated with incomplete combustion at $500^{\circ} \mathrm{C}$. The CRS obtained was then reduced in size using a ball-mill and sifted through the 350-mesh 
filter then mixed with glycerol at 30:70 (w/w) ratio. The suspension was then mixed with a magnetic stirrer (MS-HPro GSA) at 500 RPM speed for $10 \mathrm{~min}$ and sonicated (Cole Parmer) for 120 minutes to produce liquid colorant. This liquid CRS black colorant was then applied to the sago noodles mixture (300 g of sago flour mixed with $100 \mathrm{ml}$ of water) with 4 levels of additional concentrations $(0 \%$; $0.5 \% ; 1 \% ; 1.5 \%) \mathrm{w} / \mathrm{w}$. Randomized Block Design (RBD) with 1 factor was used in this research. The data obtained were analyzed by ANOVA (Analysis of Variance) $\alpha=0.05$ and continued by LSD (Least Significance Different) with $5 \%$ interval. The best treatment of analysis is done by the Multiple Attribute method [9].

Analysis on elongation was measured by using a texture analyzer (Imada) while analysis on color measured by using a color-reader (Minolta CR-100). Cooking loss was measured by cooking $5 \mathrm{~g}$ noodles sample in $150 \mathrm{ml}$ boiling water for $3 \mathrm{~min}$ in a beaker, the cooking water was collected in a tared beaker, dried to constant weight in an oven at $1030 \mathrm{C}$, then the residue was weighed and the cooking loss was calculated as a percentage of the starting material. Cooking time was measured by cooking $5 \mathrm{~g}$ noodles sample in $150 \mathrm{ml}$ boiling water until the core portion was disappeared, indicating the completion of cooking. Chemical Analysis AACC methods were followed for determinations of moisture, ash, and protein [10]. Fat and carbohydrate (by difference) was determined according to the AOAC methods [11].

\section{RESULTS AND DISCUSSION}

\section{Physical Characteristics of Sago Noodles}

The physical characteristics, including elongation, cooking loss, cooking time and color of sago noodles produced by using different concentration of liquid CRS is presented in Table 1.

\section{a. Elongation}

Table 1 shows that the elongation value of sago noodles from various concentrations of liquid CRS ranged from 24,45 to $54,45 \%$. The elongation of sago noodles is statistically affected $(\alpha=0.05)$ by the difference in the concentration of liquid CRS. The elongation value of sago noodles increased with a higher concentration of liquid CRS added. It caused by the minerals composition of CRS including calcium. According to [12], calcium can form complex structures with glucose polymers from starch, so that it can affect the firmness of the product. Calcium causes cross-linking between starch molecules, caused by $\mathrm{Ca} 2+$ binding to ion-dipole bonds. Interactions between molecules occur through intramolecular bonds or intermolecular bonds with the -OH group [13].

\section{b. Cooking Loss}

Table 1 shows that the cooking loss value of sago noodles from various concentrations of liquid CRS ranged from 2,72 to $3,51 \%$. The cooking loss of sago noodles was statistically affected $(\alpha=0.05)$ by the difference in the concentration of liquid CRS. The cooking loss value of sago noodles decreased with a higher concentration of liquid CRS added. The lower cooking loss value is the most desirable. The lower cooking loss value indicates that the noodles have a good combine and homogeneous texture [14]. The reduced of cooking loss values are related to higher elongation values, the stronger bonding between particles, they were not easy to broken and stretched when cooked [15]. Meanwhile, some minerals composition in liquid carbonized rice straw are included in alkaline group and according to the study of [16] reported that alkali can change the morphology of starch granules and reduce the electron density between the crystalline and amorphous parts of starch granules and will affect the characteristics of starch and cooking losses during the cooking processed.

\section{c. Cooking Time}

Table 1 shows that the cooking time of sago noodles from various concentrations of liquid CRS ranged from 128 to $153 \mathrm{~s}$. The cooking time of sago noodles was statistically affected $(\alpha=0.05)$ by the difference in the concentration of liquid CRS. Cooking time of sago noodles increased with a higher concentration of liquid CRS added. At a concentration of $1,5 \%$ liquid CRS colorant, the cooking time reached 153 seconds or about 2.55 minutes. According to [17], the increasing of cooking time was influenced by the increasing elongation value. It found that the bonding between the particles become stronger that would affect the time required for rehydration and slowed the water absorption then was affecting the cooking time.

\section{d. $\operatorname{Color}\left(L^{*}, a^{*}, b^{*}\right)$}

Table 1 shows the color value of sago noodles from various concentrations of liquid CRS. The color of sago noodles was statistically affected $(\alpha=0.05)$ by the difference in the concentration of liquid CRS. The brightness value $\left(\mathrm{L}^{*}\right)$ of sago noodles decreased with a higher concentration of liquid CRS added. At a concentration of $0 \%$ colorant resulting on 72.8 of $\mathrm{L}^{*}$ value and at a concentration of $1.5 \%$ colorant resulting on 29.7 of $\mathrm{L}^{*}$ value. The amount of carbon determined the black color. This is due to the higher concentration of carbon additions resulting the darker color of sago noodles.

Based on the physical analysis results, these values of $\mathrm{L}$, a, b were converted to RGB units so that the HTML code is obtained to determine the color spectrum that shows the color of the product. The color interpretation of the results can be seen in Figure 1. 
Table 1. The physical characteristic of sago noodles at different concentration of liquid CRS

\begin{tabular}{|c|c|c|c|c|c|c|}
\hline \multirow{2}{*}{$\begin{array}{c}\text { Liquid CRS } \\
(\% \mathrm{w} / \mathrm{w})\end{array}$} & \multirow{2}{*}{$\begin{array}{c}\text { Elongation } \\
(\%)\end{array}$} & \multirow{2}{*}{$\begin{array}{c}\text { Cooking loss } \\
(\%)\end{array}$} & \multirow{2}{*}{$\begin{array}{c}\text { Cooking time } \\
\text { (sec) }\end{array}$} & \multicolumn{3}{|c|}{ Color } \\
\hline & & & & $\mathbf{L}^{*}$ & $a^{*}$ & $\mathbf{b}^{*}$ \\
\hline 0 & $24.45 \pm 0.51 \mathrm{a}$ & $3.51 \pm 0.04 \mathrm{a}$ & $128.0 \pm 0.15 \mathrm{a}$ & $72.8 \pm 0.08 \mathrm{a}$ & $-0.7 \pm 0.06 \mathrm{a}$ & $4.9 \pm 0.10 \mathrm{a}$ \\
\hline 0.5 & $33.89 \pm 0.57 b$ & $3.30 \pm 0.06 \mathrm{~b}$ & $145.2 \pm 0.10 \mathrm{~b}$ & $41.8 \pm 0.06 b$ & $-1.2 \pm 0.05 b$ & $4.4 \pm 0.10 \mathrm{~b}$ \\
\hline 1.0 & $39.45 \pm 0.40 b$ & $3.16 \pm 0.07 b$ & $149.8 \pm 0.07 \mathrm{c}$ & $34.2 \pm 0.06 \mathrm{c}$ & $-2.0 \pm 0.07 \mathrm{c}$ & $3.3 \pm 0.06 \mathrm{c}$ \\
\hline 1.5 & $54.45 \pm 0.35 \mathrm{c}$ & $2.72 \pm 0.08 \mathrm{c}$ & $153.8 \pm 0.15 \mathrm{~d}$ & $29.7 \pm 0.08 \mathrm{~d}$ & $-2.1 \pm 0.10 \mathrm{c}$ & $3.2 \pm 0.03 \mathrm{c}$ \\
\hline
\end{tabular}

Different alphabetic code shows the statistical difference based on LSD test $(\alpha=5 \%)$

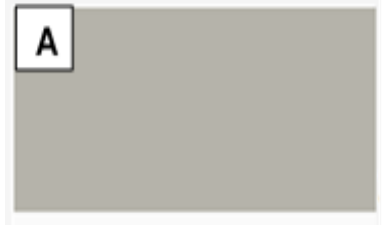

HTML: \#B5B3AA

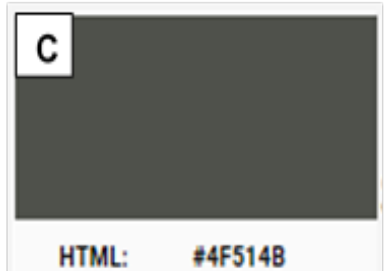

Figure 1. Color Spectrum of Sago Noodles with the addition of liquid CRS by $0 \%(\mathrm{~A}) ; 0.5 \%(\mathrm{~B}) ; 1 \%(\mathrm{C})$;

$$
1.5 \%(\mathrm{D})
$$

\section{Characteristics of sago noodles with best treatment of liquid CRS}

Based on the calculation of best treatment choice using the Multiple Attribute method, sago noodles obtained with the best treatment of the 6 parameters used is sago noodles with the addition of a liquid CRS colorant concentration of $1.5 \%$. The physical characteristics and proximate of sago noodles with $1.5 \%$ liquid CRS are presented in Table 2.

Table 2. Physical characteristics and proximate of Sago Noodles with $1.5 \%$ of liquid CRS

\begin{tabular}{|l|r|}
\hline \multicolumn{1}{|c|}{ Parameters } & \multicolumn{1}{c|}{ Value } \\
\hline Cooking loss (\%) & $2.72 \pm 0.08$ \\
\hline Cooking Time (Sec) & $153.8 \pm 0.15$ \\
\hline Elongation & $54.45 \pm 0.35$ \\
\hline Color & \\
L $^{*}$ & $29.7 \pm 0.08$ \\
$\mathrm{a}^{*}$ & $-2.1 \pm 0.10$ \\
$\mathrm{~b}^{*}$ & $3.2 \pm 0.03$ \\
\hline Moisture content (\%) & $13.2 \pm 0.13$ \\
\hline Ash (\%) & $0.81 \pm 0.03$ \\
\hline Protein (\%) & $0.23 \pm 0.06$ \\
\hline Fat (\%) & $0.04 \pm 0.03$ \\
\hline Carbohydrate (\%) & $85.76 \pm 0.05$ \\
\hline
\end{tabular}

Each data of physical analysis is the average based on 3 times of analysis; Value after \pm is the value of standard error
Table 3. Nutrition Facts of Sago Noodles with Liqid CRS of $1.5 \%$

\begin{tabular}{|l|c|c|}
\hline $\begin{array}{l}\text { Serving Size : 70 g } \\
\text { Serving per Container } \\
: 1\end{array}$ & & \\
\hline $\begin{array}{l}\text { Amount per Serving } \\
\text { Calories 240 Kkal }\end{array}$ & $\begin{array}{c}\text { Calories from Fat 0 } \\
\text { Kkal }\end{array}$ \\
\hline & & \%RDA* \\
\hline Fat & $0 \mathrm{~g}$ & $0 \%$ \\
\hline $\begin{array}{l}\text { Protein } \\
\text { Total Carbohydrate }\end{array}$ & $00 \mathrm{~g}$ & $0 \%$ \\
\hline
\end{tabular}

(*) \%RDA based on $2150 \mathrm{kkal}$ calorie diet, your daily value may be higher or lower depending on your calorie needs

Table 2 shows that the chemical characteristics of sago noodles. It has moisture content of $13,2 \%$ that fulfills the SNI requirements for instant noodles (SNI 01-3551-2000) should have a maximum moisture content of 14,5\% [18]. Moisture content will determine the texture of a food. Moisture content in materials can be influenced by several factors, including fiber content in food, protein, and starch in the product. Based on the protein content, the best sago noodles still do not meet the requirements of the protein content in SNI which is the minimum allowable value of $4 \%$ if it is not made from wheat flour.

\section{Nutrition Facts of Sago Noodles with The Best Treatment}

Information on the nutritional value of sago noodles with the addition of liquid CRS can be seen in Table 3 . Determination of Recommended Dietary Allowance (RDA) was based on the content of protein, carbohydrates, fat, and total calories of sago noodles with the best treatment. Nutritional value information is used as a reference and information for the general public regarding the nutritional value, quality and quality of a food product. The sago noodles with a $70 \mathrm{~g}$ serving size had $240 \mathrm{Kcal}$ energy.

\section{CONCLUSION}

The concentration addition of liquid CRS on sago noodles had a significant effect $(\alpha=0.05)$ on all physical parameters namely elongation, cooking loss, cooking time and color $\left(\mathrm{L}^{*}, \mathrm{a}^{*}, \mathrm{~b}^{*}\right)$. The higher addition of liquid CRS concentration, produced the higher value of elongation and cooking time yet lower the value of cooking loss, and darker the color of Sago noodles. Sago noodles from the best treatment (addition of $1.5 \%$ colorant) based on the 
Multiple Attribute test had 54.45\% elongation value; $2.72 \%$ cooking loss; 153 seconds cooking time; 29.7 brightness $\left(\mathrm{L}^{*}\right) ;-2,1$ redness $\left(\mathrm{a}^{*}\right)$ and 3,2 yellowish $\left(\mathrm{b}^{*}\right)$. The proximate test for the best treatment of sago noodles had $13.2 \%$ moisture content; $0.31 \%$ ash content; $0.22 \%$ protein content; $0.04 \%$ fat content; and $85.76 \%$ carbohydrate (by difference). Nutritional value information of sago noodles with a 70 g serving size has a total 240 Kcal energy with nutrient content (in \%RDA) of $18 \%$ total carbohydrate.

\section{REFERENCES}

[1] A. Guzman, 2015. "Valorization of Rice Straw Waste: An Alternative Ceramic Raw Material," Ceramica, vol. 61, pp. 126-136.

[2] A. Guillemot, R. Bruant, V. Pasquiou, E. Boucher, 2014. "Feasibility Study For The Implementation of Two ORC Power Plants of 1 MWe Each Using Rice Straw As a Fuel,'Enertime. Courbevoie.

[3] E. S. Murtini, S. S. Yuwono, H. Y. Setyawan, "Comparison of characteristics of carbonized rice straw from various rice varieties and parts of rice straws as a source for natural black colorant," IOP Conf. Series: Earth and Environmental Science $230012025,2019$.

[4] EFSA, 2012. "Scientific Opinion on the reevaluation of vegetable carbon (E153) as a food additive," EFSA Journal vol. 10, pp. 2592.

[5] Peraturan Kepala Badan Pengawas Obat Dan Makanan Republik Indonesia, Nomor 37 Tahun 2013 tentang "Batas Maksimum Penggunaan Bahan Tambahan Pangan Pewarna" Jakarta, 2013.

[6] L. F. Rahayu and E. S. Murtini, 2019. "The effect of carbonized merang as liquid colorant on the physics properties of noodles," AIP Conference Proceedings 2120, 050006 https://doi.org/10.1063/1.5115682

[7] A. Lerner, P. Jeremias, and T. Matthias, 2015. "The World Incidence of Celiac Disease Is Increasing: A review," International Journal of Recent Scientific Research, vol. 6, pp. 54915496.

[8] Departemen Kesehatan Republik Indonesia, 2013. "Diabetes Melitus Penyebab Kematian Nomor 6 di Dunia" http://www.depkes.go.id/article/2383,

[9] M. Zeleny, 1995. "Multiple Criteria Decision Making 2 ed", McGraw-Hill, New York, 1982.

[10] AACC, "Approved Methods of the American Association of Cereal Chemists. 91h, ed. Method 44 -15 approved Oktober 1975. Revised October 1981; Method 16-20 approved November 1989, American Association of cereal Chemist. St. Paul.
[11] AOAC, 2005. "Official Method of Analytical Chemistry," Washington D.C. University of America, AOAC Int. Washington, pp. 97-149,

[12] M. H. Lee, N. S. Hettiarachchy, McNew, Gnanasambandam, 2005. "Physicochemical Properties of Calcium Fortified Rice," Journal Cereal Chemistry, vol 72, pp. 352-355.

[13] N. Hettiarachchy, L. Paraman, and Schaefer, 2006. "Physicochemical properties of Rice Endosperm Proteins Extracted by Chemical and Enzymatic Methods," Journal Cereal Chemistry vol. 83, pp. 663-667.

[14] A. Engelen, Sugiyono, and S. Budijanto, “ Optimasi Proses dan Formula Pada Pengolahan Mi Sagu Kering (Metroxylon sagu)," Agritech vol. 35, pp. 359-367, 2015.

[15] T. Muhandri, Subarna, and N. S. Palupi, 2013. "Characteristics of Wet Corn Noodle: Effect of Feeding Rate and Guar Gum Addition," J. Teknol. dan Industri Pangan, vol. 24, pp. 110114.

[16] J. Chai, Y. Yang, J. Man, J. Huang, Z. Wang, C. Zhang, and C. Wei, 2014. " Structural and functional properties of alkali-treated highamylose rice starch," Food Chemistry, vol. 145, pp. 245-253.

[17] Mojiono, B. Nurtama, and S. Budijanto, 2016. "Pengembangan $\mathrm{Mi}$ Bebas Gluten dengan Teknologi Ekstrusi," Jurnal Pangan, vol. 25, pp. $125-136$

[18] Badan Standar Nasional, 2000. "Syarat Mutu Mi Instan (SNI 01-3551-2000),” BSN, Jakarta. 